\title{
EDITORIAL
}

\section{A Plead for the European Union Fiscal Autonomy}

\section{INTRODUCTION}

In his awarded novel, 'The Capital', Robert Menasse writes a satire about a drifting European Union, the art of survival of EU bureaucracy and officials, lobbies, and political intrigue and uses the Ark of Noah as a metaphor for an aimless Commission Directorate. 'The Capital' can be read as alert to an unsatisfactory situation, reminding us that the European peace project should be guided toward a relevant subsequent purpose. The recent German Constitutional Court (GCC) decision on the old European Central Bank's (ECB's) Public Sector Purchase Programme (PSPP) under Draghi ${ }^{1}$ that challenged the ECB independence and the EU primacy principle, the current discussions on European solidarity in the coronavirus disease 2019 (COVID-19) context and, in its aftermath, the increase of the EU own resources and the EU fiscal autonomy would be a good opportunity to overcome the EU being seen as the wandering Ark of Noah and threatened by illiberal regimes.

\section{INTERACTION BETWEEN EU MONETARY AND Member States economic policies}

The competence of the European Union economic policy is mainly fragmented between the Member States and the $\mathrm{ECB},{ }^{2}$ taking into account that the latter is the only competent entity for the monetary policy, with limits, such as the prohibition of monetary financing of Member States' budgets by central banks. In turn, Member States are the competent instances for all other (non-harmonized) fields of economic policy, including enacting those taxes that have not been harmonized and legislating about non-harmonized tax regimes. Moreover, the EU budget is approved as an expenses budget that exclusively supports the EU common policies with 'own resources' as defined in and framed by the ceilings and headings of the multiannual financial framework (MFF). ${ }^{3}$

Although it could thus be formally claimed that the monetary competence is exclusive to the EU and the fiscal competence shared between the EU and the Member States, in real life, however, monetary and fiscal performance interact, and no monetary policy decision is deprived of economic effects and vice-versa. This is because demand and supply of Member States' public debt will not only have repercussions on the national public debt rating but also on the demand and supply of the euro and its exchange-value as currency.

The same interaction is true for the ECB monetary and Member States' fiscal policies, because intervention by the ECB in the markets to support states' public debt will imply cheaper money, lowering Member States' interest rates and potentially causing inflation but also sustaining the euro exchange-value. This interaction also occurs because both the ECB and Member States act as players in the market and in accordance with the market rules.

The story is familiar. Member States' high (fiscal) debt weakens the euro, leads to fragmentation of the financial markets, national balance of payments imbalances, and burdens future generations with national taxes. Public debt bought or issued by the ECB as a response to the former is in the intersection between fiscal and monetary since it will have repercussions on the value of the common currency and on the price of commodities and will have to be later funded by raising (states') taxes.

The interaction between the ECB monetary policy and the states' economic policies occurs because the Member States are no longer competent to devalue the(ir) currency in the event of high levels of debts, and the EU does not have the competence to create taxes. Moreover, the unanimity rule hinders both the approval of directives that would require states to set up new taxes in the interest of the Union and the approval of decisions establishing new categories of own resources or abolishing an existing

\section{Notes}

DE: Second Chamber of the Constitutional Court, 5 May 2020, Joint cases 2 BvR 859/15, 2 BvR 1651/15, 2 BvR 2006/15, 2 BvR 980/16.

See the detailed explanation of the regime in E. Traversa \& G. Bizioli, COVID-19 and Solidarity in the European Union: Paving the Way for a Genuine EU Tax?, in this issue, at 743 .

European Council, Multiannual financial framework for 2014-2020, https://www.consilium.europa.eu/en/policies/eu-budgetary-system/multiannual-financial-framework/ mff-2014-2020/ (accessed 2 June 2020). The EU's expenditure for 2014-2020 is divided into six broad categories, or 'headings': (1) Smart and inclusive growth; (2) Sustainable growth: natural resources; (3) Security and citizenship; (4) Global Europe; (5) Administration and (6) Compensation. 
category. ${ }^{4}$ The previously described interaction is, in fact, a dependence relationship, often generating a loss-loss situation.

The major problem then lies on the strictly formal division of competences between the EU and the Member States on economic policies and its different consequences and manifestations: the above illustrated interactions and repercussions but also the relationship between EU law and the Member States' constitutional principles, EU institutions and Member States sovereignty organs, democratic legitimacy and, ultimately, the future of the Euroland and the European Union.

\section{The German Constitutional Court decision on the old European Central BANK PUBLIC SECTOR PURCHASE PROGRAMME}

The aforementioned GCC decision on the PSPP ${ }^{5}$ illustrates the problems resulting from the interaction of EU law and national law, the division of competences between the EU and the Member States, and the fact that the EU does not have its own taxes.

The GCC was asked, among others, to decide on:

the omission on the part of the Federal Government and the Bundestag to take steps to ensure the rescission or non-implementation of the Decision of the Governing Council of the ECB of 22 January 2015 on an expanded asset purchase programme and several decisions (from 2015 to 2018) on a secondary markets public asset purchase programme; the domestic applicability and implementation of the aforementioned decisions; the omission on the part of the federal government to take suitable steps against the ECB in the form of its PSPP by which the said bank allegedly exceeded its monetary policy mandate and violated the prohibition of monetary financing of Member States' budgets by central banks; the potential violation of the German's constitutional identity by the ECB.

The GCC decided that the aforementioned PSPP violates the principle of proportionality as it goes beyond the monetary policy objective and provokes a variety of economic, fiscal, and political costs. The GCC suspects that the PSPP is a form of debt mutualization and, therefore, an infringement of democracy in Germany. However, the GCC affords the ECB an opportunity to present, within three months, stronger justifications to the said programme in order to demonstrate its proportionality.

Meanwhile, the GCC requires its government, parliament, central bank, and courts to revert the ECB policy and not implement its acts. It further states that the ultra vires act is not applicable in Germany and, therefore, the ECB should not purchase German bonds under such a programme.

From a mere legal perspective, by questioning the ECB competence to approve the PSPP, the GCC does not respect the EU principle of primacy, and this justifies an infringement procedure against Germany. Formally, this problem may be easily overcome, specifically if the ECB adopts a new decision with a more detailed justification explaining the proportionality of the programme. This would be so even if the ECB is not under the Member States' jurisdiction, and the GCC decision undermines the ECB independence. It is not expected that the ECB will issue a new decision, however, it can provide additional information to the Bundesbank, allowing more support to the latter on the assessment of proportionality.

In this case, the German public authorities will implement the PSPP, avoiding the difficult position to choose between complying with their constitution or with EU law. This also means that there will be no EU law infringement by Germany due to its challenging the primacy of EU Law.

\section{Consequences of the German Constitutional Court decision on FUTURE EU FINANCIAL ASSISTANCE}

From a substantial perspective, the GCC judgment on the proportionality principle is not consistent. It requires the ECB to assess the economic, fiscal, and political costs derived by the PSPP to (some) Member States but does not require it to examine the benefits to (some) Member States or, what would be more rigorous, the European Union itself. Such an analysis on the balanced outcome (proportionality) of the PSPP to the EU economy and integration has not been undertaken by the GCC.

Although the decision is not about the current Pandemic Emergency Purchase Programme, it will have repercussions on the latter. This is especially so because the GCC judgment interprets the several conditions that are part of the PSPP as being necessary to demonstrate that the ECB does not exceed its competence under Article 123 TFEU: volume of purchases limited in advance; purchase limit of $33 \%$; and purchases carried out according to the capital key of the ECB, among others. These conditions are no longer part of the new purchase programme.

The GCC judgment will also have consequences on any future financial assistance decisions to be taken in the EU to address the COVID-19 crisis, on the primacy principle of EU law, and on the relationship between the Court of Justice of the European Union and states' constitutional

\section{Notes}

See the explanation and discussion on the disconnection between the EU taxing powers and the rules determining the resources funding the EU budget in Traversa \& Bizioli, supra $\mathrm{n}$. 2 .

Decision on DE: Joint cases 2 BvR 859/15, 2 BvR 1651/15, 2 BvR 2006/15, 2 BvR 980/16, supra n. 1. 
courts. The GCC judgment is a dangerous path to be explored by illiberal regimes in the EU and ultimately a menace to the survival of the EU itself.

\section{THE NeEd fOR EU fiscal AUtonomy}

It is herein contended that the GCC is read as an opportunity and necessity for the EU to move towards fiscal autonomy so that genuine risk sharing can be implemented, and debt mutualization and constitutional limits are no longer at stake. In the current context of the COVID-19 pandemic, the joint French and German proposal for a EUR 500 billion relief fund and a proposal by the Commission aiming to reinforce the MFF for 2021-2027 go in the right direction.

The Commission proposes a total amount of EUR 1100 billion by including recovery programs post-COVID (the European Recovery Instrument, 'Next Generation EU'). Recovery programmes amount to EUR 750 billion $^{6}$ and may reach $1.6 \%$ of the Gross National Income (GNI) in the EU instead of the usual circa $1 \%$ of the GNI. A green own resource, a simplified value added tax-based own resource, a digital tax applied on companies with a turnover above EUR 750 million, and an own resource on companies that draw huge benefits from the EU single market and will survive the crisis are among the proposals. $^{7}$

To approve and implement new own resources is the necessary step to avoid overlapping of the EU and Member States' economic competences, policies and measures, and the corresponding EU law and constitutional frictions and infringements. Fiscal autonomy by the EU, approved by the Parliament and the Council, will comply with democratic legitimacy and guarantee that the EU interest as a whole, as interpreted by its instances, is pursued.

\section{Ana Paula Dourado Editor-in-Chief} Miguel Poiares Maduro

(Professor, School of Transnational Governance, European University Institute; Former Advocate General, European Court of Justice)

Email:Miguel.Maduro@eui.eu.

\section{Notes}

6 European Commission, Communication from the Commission to the European Parliament, the European Council, the Council, the European Economic and Social Committee and the Committee of the Regions, The EU Budget Powering the Recovery Plan for Europe, COM(2020) 442 final (27 May 2020).

7 An own resource based on the Common Consolidated Corporate Tax Base, was put forward in 2018: European Commission, Commission Staff Working Document, Financing the EU Budget: Report on the Operation of the Own Resources System Accompanying the Document Proposal of a Council Decision on the System of Own Resources of the European Union, SWD(2018)172final (2 May 2018). 